\title{
Article \\ Development of Game-Based M-Learning Apps for Preschoolers
}

\author{
Dionísia Laranjeiro
}

check for

updates

Citation: Laranjeiro, D. Developmen of Game-Based M-Learning Apps for Preschoolers. Educ. Sci. 2021, 11, 229. https://doi.org/10.3390/

educsci11050229

Academic Editor: James Albright

Received: 16 April 2021

Accepted: 8 May 2021

Published: 12 May 2021

Publisher's Note: MDPI stays neutral with regard to jurisdictional claims in published maps and institutional affiliations.

Copyright: (c) 2021 by the author Licensee MDPI, Basel, Switzerland. This article is an open access article distributed under the terms and conditions of the Creative Commons Attribution (CC BY) license (https:// creativecommons.org/licenses/by/ $4.0 /)$.
CIDTFF-Research Centre on Didactics and Technology in the Education of Trainers, Department of Education and Psychology, University of Aveiro, 3810-193 Aveiro, Portugal; dionisia.mendonca@ua.pt

\begin{abstract}
Recent studies indicate tablets as the preferred devices of preschool children, due to portability, autonomy of use and variety of apps. There is also extensive evidence of the contributions of digital technologies in different areas of learning at these ages. The Aprender XXI project aimed to develop game-based learning apps, with content recommended in the Curriculum Guidelines for Pre-School Education (CGPE). The project used Design-Based Research (DBR) methodology, which combines scientific research and technological development. It was divided into three phases: preliminary study (literature review, search for existing apps, study of preschool curriculum), development (specifications, scriptwriting, design and programing) and evaluation (tests with users and conclusions). The preliminary study identified the needs to define robust apps. The evaluation with children and educator validated the development and defined improvements in the apps. As a result, we obtained four thematic apps-environment, health, citizenship and professions, composed of a set of games, suitable for autonomous use for children or for educational activities guided by educators in kindergarten. In addition, a website collects children's play data, which is represented with flowers in a virtual world, to illustrate their participation/collaboration for a better future.
\end{abstract}

Keywords: game-based learning; mobile learning; educational apps; kindergarten; design-based research

\section{Introduction}

Today's children belong to a generation that is familiar with technologies, such as computers, tablets and the internet. Prensky [1] called this generation "digital natives", affirming that digital language is part of their lives and it can even change their thinking patterns. It is important to understand some characteristics and skills of these children to provide interesting learning, such as recognizing that they are used to receiving large amounts of information and instant gratification, they prefer access to non-linear information, they like to network and perform various tasks at the same time. This argument is criticized by Thomas [2], claiming that the concept of digital natives presupposes a homogeneous generation, which learns differently from previous generations. Hattie and Yates [3] reinforce that human capabilities are not that malleable. There is no scientific evidence that living in an age dominated by new technologies causes changes in the brain organization or in cognitive abilities. The European Commission assumed a balanced perspective, declaring that children up to eight years old can easily acquire digital skills but their abilities are limited to the level of cognitive development. Additionally, some children show more interest and skills than others. Their lives are not dominated by technologies, as they carry out many other activities. Sometimes children use technologies to complement their offline interests, for example, to search online and photograph [4]. The use of ICT in kindergarten is not consensual and there is still some resistance to integration in this educational context, caused by several reasons: lack of conditions and outdated devices in kindergartens, lack of adequate training for kindergarten teachers, beliefs of some parents and educators that the use of technologies at these ages is not beneficial [5]. These concerns are supported by researchers and child advocacy groups who argue that technologies can 
impede physical, emotional, cognitive and social development in early childhood. Some risks include obesity, eyestrain, sleep disorders and social isolation [6]. Larry Cuban [7] claims that research on the use of technology in the learning of preschoolers is limited and ambiguous, and it cannot be confirmed whether preschoolers should use computers, for how long, for what tasks and under what conditions. Richard Mayer [8] agrees that there are strong claims about the potential of technology in transforming education that has not been scientifically tested. However, these high expectations have led to massive implementations of technological interventions in schools that have had failed results. He believes that the problem lies in the approach to learning with technology, which is focused on technology while it should be focused on the learner. In a technology-centered approach the goal is to give access to the latest technology, hoping that teachers and students will adapt and use it. The learner-centered approach focuses on the learner, the way learning happens and how the mind works. In this approach, it is technology that is adapted to the needs of students and teachers. The joint position statement of NAEYC and the Fred Rodgers Center argues that if the integration of technology in kindergarten is built upon solid developmental foundations, and educators are aware of the challenges and opportunities, the quality of the educational program is improved by using technologies for the benefit of all children. Some recommendations are that educators have digital literacy to make informed choices that can maximize learning opportunities; they should monitor the time and use of devices by children; technology must be used to support learning and expand access to new content. It should not replace creative games, outdoor experiences, and interactions with children and adults [9]. The American Academy of Pediatrics also set recommendations to help families with young children promote healthy media use. At home, children aged two to five should use the media together with their parents to help them understand the content. Use should be limited to one hour a day, with a pre-selection of quality content. From the age of six, parents must define time limits, locations and types of media that can be used, maintaining balance with physical activity, reading, social interaction and other activities essential to health. Children should not use screens one hour before going to bed, to avoid sleep disturbances [10]. Despite all the concerns and risks identified, extensive literature documents the contributions of digital technologies in the learning and skills development of pre-school children [11-13]. In language development, digital technologies can impact the fluency and complexity of speech, the development of verbal communication and written language, vocabulary, syntax and word recognition [14]. As examples, the use of word processing software can enhance the understanding of written code, and the creation of podcasts can enrich orality, expression and communication [15]. In math, there are specific applications that stimulate mathematical concepts, such as counting, classification or logical thinking. Drawing programs develop geometric and spatial knowledge. Programing encourages creative thinking and problem solving [14]. Internet allows contact with other natural, social and cultural realities. A good example is the use of Google Earth ${ }^{\circledR}$ for an interactive and precise exploration of the world, to understand space and local geography in relation to global geography [15]. Using various technologies, pre-school children acquire digital literacy, which includes the ability to search online, use the mouse and touchscreen and create multimodal texts [12]. For the development of artistic skills, there are interactive tools and environments, which can be used for exploring music, drawing, painting, animation, creative writing, poetry and storytelling. These are usually open-ended applications, quite versatile and adaptable to different contexts, and it is up to the educator to plan their use in learning activities. With regard to develop preschoolers' cognitive skills, carrying out learning activities based on apps and digital games improves abstract thinking, reflection, analysis and evaluation of information, problem solving, spatial representation, attention and memorization [13]. Social tools foster learning and teamwork, by providing communication and collaboration features, which can be used in group projects, in the classroom or remotely. This type of activities promotes interaction, team spirit and develops language and critical thinking. Exposure to other perspectives and divergence of opinions stimulates dialogue and joint 
analysis of possibilities, which results in higher quality decisions. All this involvement increases the interest in the content and leads to better learning performances [16]. Despite the rapid evolution of technologies, there are some propositions in the literature with more than twenty years similar to the current ideas, regarding children of preschool age: they write on the keyboard and use computers and software with confidence; they face difficulties as challenges and almost always manage to overcome them; computers help children to learn, so the educator has to know how to help them, assuming a less instructional and more guiding role; computers encourage social interaction and communication, as children prefer to work with friends and talk while they work; cooperative work on the computer generates enthusiasm and interest in the activity; children with special educational needs can benefit from digital technologies, in physical, emotional and social terms $[17,18]$.

Recent studies point out that access to mobile devices is universal for children up to eight years old and indicate tablets as their favorite devices. Using comparative data from 2011 and 2017, a report on the use of screen media by North American children ages zero to eight points out that the major change has occurred in the type of devices rather than in screen time, which remained approximately $2 \mathrm{~h}$ a day. The use of mobile devices has increased substantially (from 5 to $48 \mathrm{~min}$ a day) while the use of television, DVD players, computers, and video game consoles has decreased. The study indicates that $95 \%$ of children aged zero to eight have a smartphone at home and $42 \%$ have their own tablet. $67 \%$ of parents believe that the use of digital media helps their children in learning [19]. In Portugal, a study on the use of technology in early childhood also indicates the tablet as their preferred device. In terms of consumption, $50 \%$ of children play digital games and $50 \%$ of children aged three to five who access the internet, use their own tablet [20]. The mobile market has brought a wide range of educational apps that integrate different ways of understanding, knowing and expressing, valuing the multiple forms of intelligencelinguistic, mathematical, creative and artistic. A learner with access to a selected set of educational apps can perform activities in languages, arts, sciences, among others [21]. Children in pre-school education can benefit from the characteristics of tablets, due to the appropriate size, portability and long battery life, which gives them autonomy in use and allows them to explore apps in various locations. The possibility of multitouch interaction also favors joint use with friends, educators and parents. There is a wide variety of apps with multimodal content, available for different educational purposes and appropriate for these ages [22]. Educational apps can be classified into three levels: instructional apps, based on exercise-reward, aimed at the acquisition of specific content and skills; manipulable apps that manage ideas and content, allowing multiple responses to a set of variables; constructive apps, with an open structure that serves to create or communicate, allowing learners to build a learning object from a set of available components. In terms of contribution to cognitive development, there is a growth in the learner's involvement and motivation from instructional to constructive apps [23]. Most educational apps are not directly related to specific curricular themes, but have versatility and flexibility to be used in different contexts.

In the development of digital pedagogical applications, it is necessary to take into account three components that influence learning: the child (to whom it is addressed), the adult (who guides learning) and technology. Older children, with previous experience, longer exposure and access time at home, can benefit more from technology in learning [12]. Adults have a mediating role, whether they are parents or kindergarten educators. They can plan and guide activities with technology, prepare questions, encourage interaction and experimentation. They must monitor the screen time and use of technological devices, support and intervene when necessary, promoting gradual autonomy [24]. With regard to technology, design mechanisms, teaching-learning approaches and content are conditioning factors for learning [12]. In terms of design, pedagogical applications for children must use graphics and actions that provide context; they must use simple and clear instructions, based on images; they must have an intuitive interface and interactivity for independent use, but also a challenging approach with multiple opportunities for 
success, to maintain interest [24]. They must have clear and understandable feedback mechanisms for the child, that make connections between actions and results, guiding the child's performance. The content must be appropriate and meaningful to the child, allowing to explore different domains (cognitive, physical, emotional) and offering opportunities to complement learning with offline activities, such as drawings or playing games outside [25]. Digital games are a very appealing type of multimedia content for children, which can be used in the teaching-learning process. The learning of younger children is intuitive and action-oriented. Children experience and discover reality through error and success, observing the consequences of their actions, influenced by the context, with the support of adults [26]. While playing games, children have an interested and cooperative attitude. They are active in the search for information and oriented to achieve results [27]. Games present content in a fun way and give opportunities to practice, with immediate feedback on the results. They allow children to experience and solve challenges, encourage collaboration, teach how to respect rules, how to work individually and as a team. Games provide variety and flexibility of learning, for example, there may be individual games, games for small or large groups, closed or open games [28].

This paper presents the project Aprender XXI, an enterprise R\&D project, involving a research team, a technological team and the participation of users from a kindergarten. This project aimed to develop mobile apps to promote the learning of pre-school children, using game-based learning strategies and addressing content areas, according to the CGPE, from the Portuguese Ministry of Education [29]. Technological development was driven by scientific research, to generate rigorous knowledge about the development process and the results achieved. The project lasted 24 months and adopted the DBR methodology, as it was considered an appropriate methodology for the context and the defined objectives.

\section{Materials and Methods}

The term DBR encompasses a group of research methodologies based on design and development, which have common characteristics [30], such as-design experiments [31], development research [32], educational design research [33].

This methodology allows exploring the potential of technologies in education to solve a real problem, bringing practical and scientific contributions [32]. It may include the development of technological products, materials and instructional activities that use technologies. DBR includes problem analysis, design and conception of an educational prototype, evaluation and review activities [34]. The user must be involved in the design and development process, namely in the use and evaluation of the prototype [35]. Scientific knowledge influences development, which is then tested in the field, bringing empirical data to improve the product and validate knowledge [32]. In conclusion, DBR is based, on the one hand, on rigorous and reflective research to build knowledge and design principles that can guide developments. On the other hand, it seeks to solve concrete problems, involving users and acting on the context [36].

For all these reasons, DBR methodology was chosen for the development of this project. The Aprender XXI apps were designed to explore the potential of mobile game-based learning in kindergarten. A kindergarten classroom was involved, with the participation of an educator and 22 children in the development process, which means that the prototypes of the apps were used and evaluated in the context (kindergarten), to be corrected and improved in a final version. The results achieved are the final versions of four game-based learning apps for preschool children.

The model proposed by Plomp [33] to operationalize the DBR methodology was adapted to the project, divided into three phases: Phase 1-preliminary study, which included the literature review, search for solutions that already exist in the market and acquisition of knowledge regarding learning contents and skills to be acquired at preschool age; Phase 2-development, started with the writing of technical specifications of the apps, the choice of learning content to be included in the apps, the adaptation and script of digital content, design and programing of technological products; Phase 3-evaluation, which 
included tests with users in kindergarten and product improvements, ending with the final versions of the apps.

\subsection{Preliminary Study}

The first phase was the preliminary study necessary for the development of gamebased learning apps for children aged three to six years old. A literature review on children's learning with technology and games served to contextualize and substantiate the theoretical framework and to become aware of research already performed, such as recent cases of use of apps in learning practices in kindergarten. The platforms Scopus and Web of Science were selected for search and constitution of the documental corpus. In order to contemplate national projects, searches were also carried out in national journals and repositories of the Portuguese Universities. Further, complementary search was done on the aggregator system Google Scholar. Research equations were combinations and variations of the terms: apps/tablets, kindergarten/preschool and children/toddlers. The research was carried out in Portuguese and English languages. As criteria for inclusion, researchers considered articles of scientific journals, research reports, conference proceedings and doctoral theses with theoretical discussions and practical experiences of using apps for learning in kindergarten. Documents centered on other levels of education, or technologies that fell outside the scope (e.g., websites, CD-ROM) were excluded. Since it is not the objective of this article to present the entire literature review, some studies were selected to be presented in the "results of the preliminary study" section, due to their relevance to the project.

Another preliminary study carried out was the search and selection of educational apps suitable for these ages, to learn more about the "state of the art" and understand the existing offer that can be used in an educational context, identifying the features they offer, innovations, trends and good practices, as well as weaknesses that can be suppressed. To this end, a search was made for apps available in online stores (App Store ${ }^{\circledR}$ and Google Play $^{\circledR}, 2017$ versions). These stores have limitations in terms of organization, search and filtering, making it difficult to select apps, in an immense offer with daily growth. Thus, it was decided to select the most prominent apps in stores, by the number of comments or downloads. At the same time, a web search was done, combining some terms (apps, children/kids, kindergarten/preschoolers, learning, games) to find lists of apps and reviews from experts that reflect on the most used and well positioned apps for these purposes. This research allowed to find app sites, with information about their educational approach and content. In the Stores, it was possible to view demonstration videos and download the apps to test. Some apps were excluded because they were outside the scope of the project. As a result, a solid set of apps was obtained, to be subsequently evaluated. The evaluation considered dimensions relevant to the educational level, establishing the categories of analysis based on the CGPE. In relation to game dynamics, the presence of rules, obstacles and quantification of actions was verified. In terms of skills development, the possibility of creating, building, collaborating or cooperating was considered. Regarding the content, it was analyzed whether the focus was scientific, simulation of reality, or storytelling.

Since this project focuses on children aged three to six, who may attend kindergarten, it was necessary to understand what the approaches were to formal learning for children of this age group, as apps must respond to educators' pedagogical practices in order to be efficient. To this end, CGPE and educational guidelines from other European countries were studied, in order to define appropriate content at national level, but with the potential for internationalization.

\subsection{Development}

Based on the results of the preliminary study, the development phase began. Technological development consisted of a set of activities that were divided into smaller tasks with defined objectives, deadlines, human resources and dependencies. It started with the definition of specifications-detailed descriptions of what needs to be developed to 
respond to the identified needs. The specifications delimit the scope of the project and present guidelines, common to the different functions and team members: content creation, design and programing [37]. Four types of specifications were defined:

- Concept specifications-presentation of the creative concept and general approach, explaining what is common and different in all apps, how it applies in each app and on the website, how they interconnect and relate all conceptual elements;

- Design specifications-instructions for the graphical approach, interface characteristics, design and illustration components;

- Content specifications-indications about the content to be developed in each app; guidelines for screenwriting;

- Programing specifications-programing languages to be used, technologies to support development.

After defining the specifications, content planning started, with the choice of themes and subthemes for each app, based on the CGPE. Screenwriting described what appears on each screen, in terms of content, graphics, interaction, feedback and sound. After the specifications and content were defined, the design began, with graphic studies, creation of characters, scenarios, objects and animations. The content was programed in four apps for mobile devices (Android ${ }^{\circledR} 4.0 .3$ or later and iPads ${ }^{\circledR}$ OS 8.0 or later) and an integrating website. The development also included internal tests, before the evaluation with users. In the internal tests, errors were corrected and interaction details were changed to improve the user experience.

\subsection{Evaluation}

The evaluation phase aimed to test the prototypes with users, to correct or validate the direction of technological development. It was carried out in a kindergarten classroom, with an educator and 22 children, aged three and six years old, as the use in the context and the interaction between users was essential for the evaluation [38]. Data collection was based on the observation of the use of prototypes by the children and the educator. At the end of the observation sessions, an interview was conducted with the educator. The specific objectives of this evaluation were:

- Obtain data from the observation of children using the apps-data related to the user experience (check if the interface was intuitive, easy to learn and use, check if the objectives were understood) and the importance given to the content (understanding, interest, games played more times);

- Obtain data on the educator's perception-usefulness of games and content, dynamics and activities that can be developed with the apps, usage expectations;

- Analyze the data, as a way of evaluating the prototypes. Making decisions about necessary changes, to improve the apps in the final versions.

Some kindergartens were identified in order to integrate a group of children in the project. It should be a heterogeneous group, to test the prototypes with different ages. The educator should have a predisposition to use technologies and a willingness to integrate the project in pedagogical activities. A kindergarten classroom was intentionally selected because it complied with the prerequisites. The invitation was formally made to the institution and the project was presented to the educator, who transmitted the information to the parents and obtained informed consent. The pilot project was approved and took place at the kindergarten, during the first period of the 2018-19 school year, involving the kindergarten teacher and her group with 22 children between the ages of three and six years old.

The data collection technique chosen was participant observation, as it is useful for studying small groups and events that last a short time. It is an opportunity to record information as it occurs in a context, to study non-verbal behaviors and people who have difficulty verbalizing their ideas, such as pre-school children [39]. Following the considerations of the authors, Cohen, Manion and Morrison [40], the observation was 
planned, defining when, where, how and what to observe. Four observation sessions were held, one for each app. The researcher interacted with the users (children and educator) in their natural environment, giving initial explanations about the apps. Then, the children used tablets to explore the apps, freely and/or with the guidance of the educator.

It was necessary to take into account some limitations of this data collection technique. The presence of an observer in the context can impact the behavior of those being observed or lead to disturbances of what is intended to be observed, which may cause changes in the outcomes of a study [41]. In a research with children, it is necessary to consider the way they look at adults, which can lead to inhibition or the search for attention and approval. It is difficult for children to accept an adult as an equal, although they can tolerate their presence in the group [42]. In this investigation, the children involved were used to receiving adults in the classroom to do specific activities, such as talking about professions, carrying out science experiments, cooking. In this sense, the researcher chose to follow the procedures they were used to, in order to reduce the strangeness element. She was introduced as a person who came to do an activity with tablets. During the sessions, she explained the games, helped the children punctually, but intervened as little as possible to make the use as natural as possible-individually, between peers or with the educator. This posture allowed the researcher to take notes during the observation, recording a large number of comments immediately, to reduce the possibility of bias in the data, which is another limitation of the observation technique [41]. An observation grid was created to fill with data collected in the sessions. The grid had a table for each app, with games identified by a name and separated by lines. In each line, there were fields to fill in, regarding the use of a child: (1) liked it or not; (2) understood or not; (3) comments during the game; (4) notes from the researcher, such as interaction with other children or with the educator. The data collected about each child were the name, age and gender, which were then stored separately and coded from C1 to C22.

Each session lasted the morning activity period. The observation was semi-structured, because it started from a set of topics that were intended to be observed, in order to obtain a rich description of the events that occurred in the context [40]. In addition, an interview was conducted as an instrument to collect more detailed and in-depth information from the kindergarten educator, to understand the possible use of apps in an educational context, and also to collect opinions and suggestions. To help conduct the interview, a guide was created with questions previously formulated to answer the objectives of the evaluation. It used open questions related to experience and opinion, to understand thoughts, beliefs and attitudes about certain topics [40]. The interview was conducted in the kindergarten. Data were analyzed to obtain the educator's perception and to assess the need to make changes in technological development.

\section{Results}

The results of each phase are presented separately and sequentially, as each phase influenced the next. The discussion and conclusions combine the results of the three phases.

\subsection{Results of the Preliminary Study}

The literature review focused on projects that contributed with results on the role of tablets in pre-school education and the feasibility of integration in this context. The complete study can be read in the preliminary study report [43]. For this article, some projects were selected in which kindergarten children used apps for learning, covering different areas of knowledge and skills. One study, on drawing activities with tablets, reports that children enjoyed the experience, showed persistence and quality in the drawings, developed familiarity with the tablet and used them progressively more time and more autonomously, over six weeks [44]. In another research, the tablet was used for literacy activities, with apps for creating narratives and acquiring vocabulary. Children understood the apps, played an active role in the games, shared the tablet, showed a good mood and communicated. The activity promoted language learning and increased speech skills [45]. 
The use of math apps in a Greek kindergarten had better results than teaching traditional mathematics [46]. The use of apps for multimedia production, in groups, generated curiosity, communication and collaborative work, stimulated creativity, hand-eye coordination and fine motor skills [47]. A dollhouse decoration game app allowed children to reproduce traditional play, work on spatial organization skills and learn the relationship between objects. At the same time, it stimulated cooperative work and creativity. A photo editing app allowed the creation of graphic compositions. These experiences showed the potential to influence the cognitive development, autonomy and creativity of children with mobile apps [48].

In the survey of educational apps for pre-school education, an extensive number of apps was found. The full study is available in the preliminary study report. A selection was made of the apps that best meet the project's goals, as they were suitable for the ages of three to six years old, and covered content areas proposed in the CGPE. As a summary, Table 1 presents some apps (or collections of apps), with categories relevant to the educational level, according to CGPE [49].

Table 1. List of selected apps. Adapted from Zagalo \& Laranjeiro (2018).

\begin{tabular}{|c|c|c|c|c|c|c|c|c|}
\hline & Open Rules & Obstacles & Scores & Build & Collaboration & $\begin{array}{c}\text { Scientific } \\
\text { Content }\end{array}$ & $\begin{array}{c}\text { Reality } \\
\text { Simulation }\end{array}$ & Storytelling \\
\hline Toca Boca & $\mathrm{x}$ & & & $x$ & $x$ & & $x$ & \\
\hline Dr. Panda & $\mathrm{x}$ & & & $x$ & & & $\mathrm{x}$ & $x$ \\
\hline Sago Mini World & & & & $x$ & & & $x$ & $x$ \\
\hline Sesame Street & & $\mathrm{x}$ & & & & & $x$ & $x$ \\
\hline $\begin{array}{l}\text { Montessory } \\
\text { Preschool }\end{array}$ & $\mathrm{x}$ & & $\mathrm{x}$ & $\mathrm{x}$ & & $\mathrm{x}$ & & \\
\hline LumiKids & $x$ & & & $x$ & $x$ & $x$ & $x$ & \\
\hline Lego Apps & & $x$ & & $x$ & & & $x$ & \\
\hline Duck Duck Moose & $x$ & & & $x$ & & $x$ & & \\
\hline Minilab & & & $x$ & & & $x$ & $x$ & \\
\hline
\end{tabular}

In general, all apps have sets of games and correspond to several categories. The most prevalent categories are the presence of open rules, which allow children to act freely; the possibility of building/construction within the game, which stimulates creativity; and the simulation of reality, with activities that are not compulsory, but closely linked to their daily lives. This emphasizes the agency of players who are in a phase of discovering themselves and others. A less interesting point is the approach to scientific content in some apps, with greater rigidity and a more instructional approach, using game logics as overcoming obstacles to score, stating the need to quantify activities. Another category rarely found was collaboration/cooperation, which may be associated with parents' fears about their children's access to the online environment, but that narrows the potential of mobile apps. It was also concluded that, in the national context, there were few apps aligned with the CGPE. The learning apps in Portuguese were scarce, more oriented to the consumer market and, tendentially, instructional. Most of the educational apps found were in English, which may be an exclusion factor for use in Portuguese classrooms, particularly in pre-school education, when children have little contact with foreign languages.

To understand the approach to formal learning in kindergarten, the CGPE and educational guidelines from other European countries were consulted, with the intention of developing apps according to the content, and pedagogical practices of kindergarten teachers. European countries provide official guides for pre-school education, in documents that refer to learning objectives at an emotional, social and intellectual level. They give indications about pedagogical approaches, learning activities and assessment methods and define skills to be developed, such as language and communication. There are differences in the learning goals defined by country, but most emphasize reading, numeracy and 
logical thinking, as well as the importance of the arts and knowledge of the world for children aged three to six. Pre-school institutions are free to decide the curriculum, the organization of activities and methodologies they want to adopt. A balance between individual and group work is recommended, and also between activities initiated by educators and children. About half of the countries believe that free play should be encouraged as an essential way of learning [50]. In Portugal, the CGPE follow an approach that is supported by the three main areas of human development: socio-affective, motor and cognitive. The document proposes that children develop through exploration and action on the world around them, with activities planned by the educator that should enhance the discovery of relationships with themselves, with others and with objects, and encourage reflection, understanding, transformation and complexification of knowledge. It distinguishes three content areas-personal and social training; expression and communication; knowledge of the world. Personal and social training integrates citizenship, multiculturality, sense of identity, education for values, such as tolerance, sharing and justice, seeking to make children conscious and supportive, with the ability to solve problems. The area of expression and communication refers to the acquisition of different forms of language, for the child to make their representations, interact with others, express thoughts and feelings. It is divided into the scientific areas of physical education, artistic education, oral and written language, mathematics. In the last area, knowledge of the world, the child's natural curiosity is stimulated, fostering new situations for discovering and exploring the world. Three components are used: scientific methodology, sciences and technologies. The CGPE recognize the child as the central element of learning and consider playing as the natural and spontaneous way of learning. It advises a holistic approach to content areas, in a process of articulated construction of knowledge [29].

\subsection{Results of the Development Phase}

After the preliminary study was completed, development began. Four apps were defined. Each app refers to a main theme, with five games that address sub-themes, accordingly with the content areas and knowledge domains defined in the CGPE.

\subsubsection{Nature Kids}

Nature Kids is an environmental education app, which explores concepts and challenges related to sustainability, biodiversity, recycling, forest and animal life preservation (Figure 1). It has five games: (1) Forest-find baby animals in the forest (squirrels, rabbits, deer...) and hand them over to their parents; (2) Feed the Farm Animals-feed the cows, chickens, pigs and other animals on a farm, according to their requests, that are presented with illustrations of food in speech bubbles; (3) Plantations-the whole process of sowing or planting until harvesting fruits and vegetables-putting seeds, water, fertilizer, watching them grow, harvesting; (4) Recycling - separate waste for the correct containers-paper, glass, packaging; (5) Meteorology_dress up characters, according to the weather conditions.

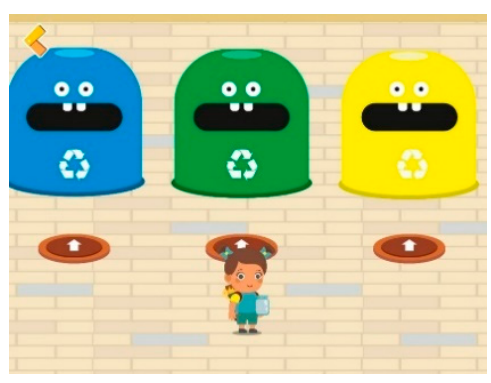

(a)

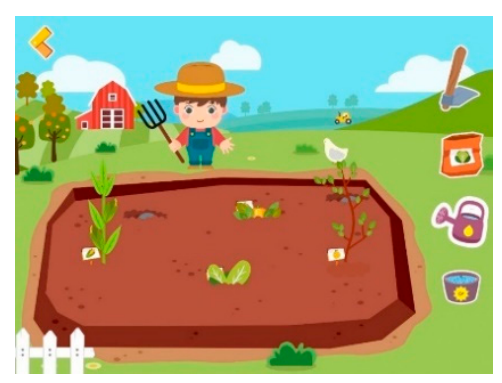

(b)

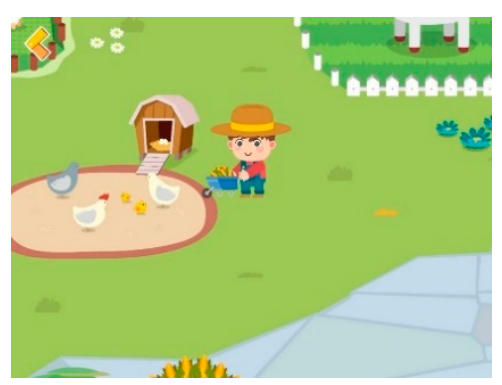

(c)

Figure 1. Print screens of games from the app Nature Kids: (a) Recycling; (b) Plantation; (c) Feed the Farm Animals. 
The main domains of the CGPE addressed in this app are the knowledge of the physical and natural world (characteristics of animals and plants, nature preservation and respect for the environment, properties of objects, climate and influence in daily life). Table 2 summarizes the learning that can be promoted by the Nature Kids app, according to the CGPE.

Table 2. Nature Kids games, content and learning.

\begin{tabular}{|c|c|c|c|}
\hline Game & Content Area & Knowledge Domain & $\begin{array}{l}\text { Learning, Attitudes, Know-How } \\
\text { That Can Be Explored }\end{array}$ \\
\hline \multirow{3}{*}{ Forest } & Knowledge of the world & Science-physical/natural world & $\begin{array}{l}\text { Characteristics of animals, identify } \\
\text { similarities and differences of animals }\end{array}$ \\
\hline & Personal and social training & $\begin{array}{l}\text { Democratic coexistence and } \\
\text { citizenship }\end{array}$ & $\begin{array}{l}\text { Respect for the other, solidarity, } \\
\text { interventional attitude }\end{array}$ \\
\hline & $\begin{array}{l}\text { Expression and } \\
\text { communication }\end{array}$ & Math & $\begin{array}{l}\text { Identify numbers, quantities, count; } \\
\text { locate objects and group by } \\
\text { characteristics }\end{array}$ \\
\hline \multirow{2}{*}{ Feed animals } & Knowledge of the world & Science-physical/natural world & $\begin{array}{l}\text { Characteristics of animals, identify } \\
\text { similarities and differences of animals }\end{array}$ \\
\hline & Personal and social training & Independence and autonomy & $\begin{array}{l}\text { Making decisions, taking into account } \\
\text { the well-being of others; distinguish } \\
\text { food and its importance for health }\end{array}$ \\
\hline Plantations & Knowledge of the world & Science-physical/natural world & $\begin{array}{l}\text { Characteristics of plants, nature } \\
\text { preservation, respect for the } \\
\text { environment; phenomena and } \\
\text { transformations in the natural world }\end{array}$ \\
\hline \multirow[t]{2}{*}{ Recycling } & Knowledge of the world & Science-physical/natural world & $\begin{array}{l}\text { Respect for the environment; } \\
\text { properties of objects, identify } \\
\text { similarities and differences of } \\
\text { materials }\end{array}$ \\
\hline & $\begin{array}{l}\text { Expression and } \\
\text { communication }\end{array}$ & Math & $\begin{array}{l}\text { Identify and locate objects; group by } \\
\text { characteristics }\end{array}$ \\
\hline Meteorology & Knowledge of the world & Science-physical/natural world & $\begin{array}{l}\text { Climate influence in daily life; } \\
\text { similarities and differences of } \\
\text { materials (clothes); } \\
\text { phenomena/transformations in the } \\
\text { natural world }\end{array}$ \\
\hline
\end{tabular}

\subsubsection{Healthy Kids}

Healthy Kids is the health education app, that addresses the subthemes of healthy eating, hygiene, oral health, physical activity (Figure 2). It has five games: (1) Creating Healthy Snacks-using available food, children can create sandwiches and drinks; (2) Supermarket-shopping for healthy food at the supermarket, selecting options from the shelves. When passing the food in the cashier, it will check if the choices are healthy; (3) Dentist - going to the dentist, clean the teeth, treat caries and put a brace; (4) Physical Activity - choose an activity to train outdoors, such as cycling, rollerblading, skateboarding; (5) Beach-going to the beach, put on sunscreen, put on a cap, stay in the shade, play in the sand, see the flags. 


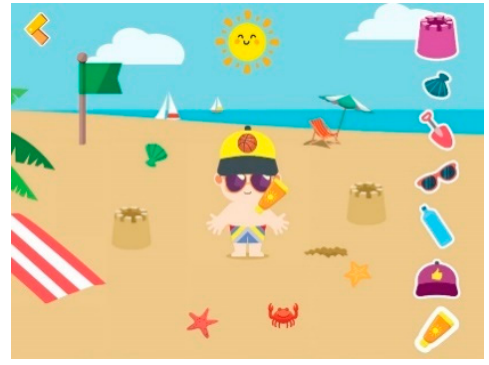

(a)

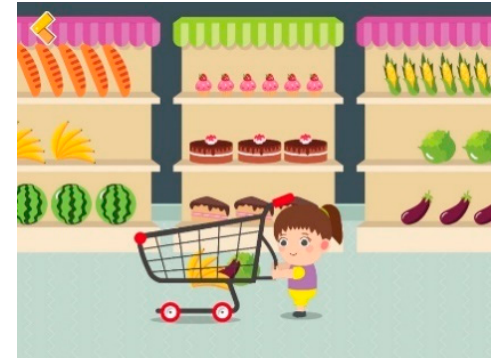

(b)

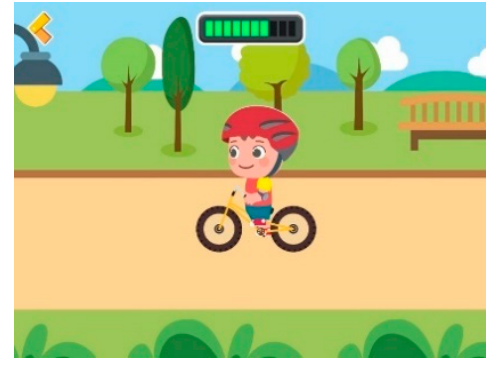

(c)

Figure 2. Print screens of games from the app Healthy Kids: (a) Beach; (b) Supermarket; (c) Physical Activity.

The main learning contents relate to health care and safety of the body, well-being and responsible choices, which are included in the areas of world knowledge and personal and social training of the CGPE. Table 3 summarizes the learning that can be promoted by the Healthy Kids app, according to the CGPE.

Table 3. Healthy Kids games, content and learning.

\begin{tabular}{|c|c|c|c|}
\hline Game & Content Area & Knowledge Domain & $\begin{array}{c}\text { Learning, Attitudes, Know-How } \\
\text { That Can Be Explored }\end{array}$ \\
\hline Healthy Snacks & Personal and social training & Independence/autonomy & $\begin{array}{l}\text { Knowing how to take care of their } \\
\text { well-being; understand the } \\
\text { importance of healthy habits and } \\
\text { healthy foods; ability to make good } \\
\text { choices; distinguish food and its } \\
\text { importance for health }\end{array}$ \\
\hline \multirow[t]{2}{*}{ Supermarket } & Personal and social training & Independence/autonomy & $\begin{array}{l}\text { Knowing how to take care of their } \\
\text { well-being; Understand the } \\
\text { importance of healthy habits and } \\
\text { healthy foods; ability to make good } \\
\text { choices; distinguish food and its } \\
\text { importance for health }\end{array}$ \\
\hline & $\begin{array}{l}\text { Expression and } \\
\text { communication }\end{array}$ & Math & Count objects, identify numbers \\
\hline \multirow[b]{2}{*}{ Dentist } & Knowledge of the world & Science-physical/natural world & Health care and safety of the body \\
\hline & Personal and social training & $\begin{array}{l}\text { Independence/autonomy; } \\
\text { identity and self-esteem }\end{array}$ & $\begin{array}{l}\text { Understand the importance of rules, } \\
\text { healthy habits and personal hygiene, } \\
\text { such as washing the teeth and going } \\
\text { to the dentist }\end{array}$ \\
\hline \multirow[b]{2}{*}{ Physical Activity } & Knowledge of the world & Science-physical/natural world & Health care and safety of the body \\
\hline & Personal and social training & Independence/ autonomy & $\begin{array}{l}\text { Understand the importance of rules, } \\
\text { healthy and personal hygiene; why it } \\
\text { is important to exercise regularly }\end{array}$ \\
\hline \multirow[t]{2}{*}{ Beach } & Knowledge of the world & Science-physical/natural world & $\begin{array}{l}\text { Health care and safety of the body; } \\
\text { understand phenomena and } \\
\text { transformations in the natural world }\end{array}$ \\
\hline & Personal and social training & Independence/autonomy & $\begin{array}{l}\text { Make responsible decisions for their } \\
\text { well-being and safety }\end{array}$ \\
\hline
\end{tabular}

\subsubsection{Citizen Kids}

Citizen Kids in the citizenship app, that addresses the subthemes of civility, multiculturalism and preservation of cultural heritage (Figure 3). It has five games: (1) Play Areas-distribute children in the areas of the kindergarten classroom. In each area, there 
can only be a certain number of children (e.g., dollhouse can have 4 characters, library-2, paintings-3). The player has to distribute the characters in the areas, taking into account their wishes that are shown in thought bubbles. When there are too many characters wanting to go to an area, they have to wait for their turn. They stay in the queue, until the player removes one that has been there for a long time. (2) Playground-distribute characters in the playground, similarly to the previous one, but outside. The characters must be distributed among different spaces: slide, sandbox, hopscotch, soccer. (3) Behavior Board-a board divided into two sides. On the left side there is the correct symbol and on the right side there is the wrong symbol. In the game, children explore a room where they discover notes with correct attitudes (lift the finger to speak) and wrong attitudes (push, throw tantrums) and they can build a board, choosing the correct and wrong behaviors, with the notes they prefer. (4) Clothes of the World-dress dolls with clothes that represent different countries and customs in the world. Players can choose a country on the map and see the typical costume. Then they can open the closet to choose clothes and dress the doll according to the costume or otherwise, as they wish. When they open the closet the clothes change, to give them several options; (5) Preservation of Heritage- on a walk down the street, the character goes through places that he can help preserve, for example, picking up papers from the floor, washing a statue with a hose, fix a broken church-stained glass, tearing wall posters.

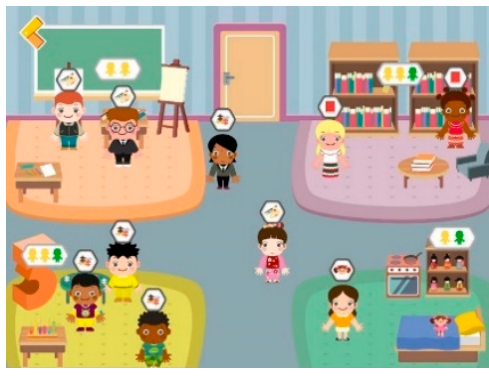

(a)

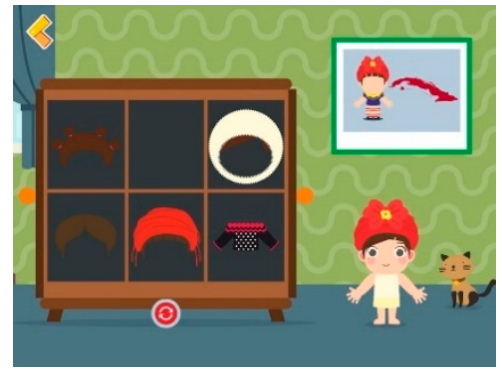

(b)

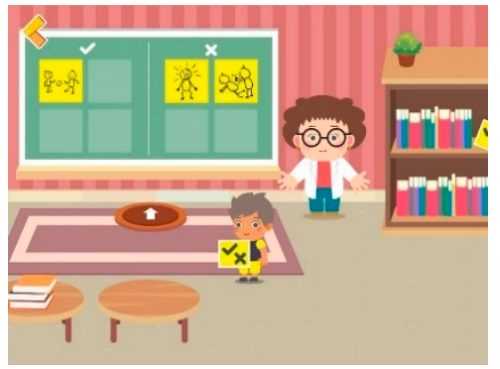

(c)

Figure 3. Print screens of games from the app Citizen Kids: (a) Play Areas; (b) Clothes of the World; (c) Behavior Board.

Citizen Kids app addresses the CGPE, in the field of personal and social training, areas of democratic coexistence and citizenship, exploring contents about civility and rules of living in society, multiculturalism and diversity, solidarity and preservation of the natural and cultural heritage. Table 4 summarizes the learning that can be promoted by the Citizen Kids app, according to the CGPE.

\subsubsection{Busy Kids}

Busy Kids is the profession awareness app that offers games about different jobs and routines (Figure 4). It has five games. (1) Postman-the character has to sort mail, deliver mail to addresses in a street, following a map and directional arrows to advance in the scenario. (2) Fashion Designer-the player chooses fabric patterns, cuts fabrics according to shapes, decorates clothes with props; (3) Builder-mix cement, lay bricks, build walls according to different geometric shapes; (4) Office Worker-uses the computer, answers the phone, uses paper, pens, stamps and other office supplies. (5) Mechanic-changes tires, paints cars, replaces headlights, among others. 
Table 4. Citizen Kids games, content and learning.

\begin{tabular}{|c|c|c|c|}
\hline Game & Content Area & Knowledge Domain & $\begin{array}{c}\text { Learning, Attitudes, Know-How } \\
\text { That Can Be Explored }\end{array}$ \\
\hline \multirow[t]{2}{*}{ Play Areas } & Personal and social training & $\begin{array}{l}\text { Democratic } \\
\text { coexistence/citizenship; } \\
\text { Independence/autonomy }\end{array}$ & $\begin{array}{l}\text { Respect for the other, solidarity, } \\
\text { critical and interventional attitude } \\
\text { towards the world around them, } \\
\text { making decisions taking into account } \\
\text { the well-being of the other }\end{array}$ \\
\hline & $\begin{array}{l}\text { Expression and } \\
\text { communication }\end{array}$ & Math & $\begin{array}{l}\text { Identify numbers, identify, count and } \\
\text { locate objects; group objects by } \\
\text { characteristics }\end{array}$ \\
\hline \multirow[t]{2}{*}{ Playground } & Personal and social training & $\begin{array}{l}\text { Democratic } \\
\text { coexistence/citizenship; } \\
\text { Independence/autonomy }\end{array}$ & $\begin{array}{l}\text { Respect for the other, solidarity, } \\
\text { critical and interventional attitude } \\
\text { towards the world around them, } \\
\text { making decisions taking into account } \\
\text { the well-being of the other }\end{array}$ \\
\hline & $\begin{array}{l}\text { Expression and } \\
\text { communication }\end{array}$ & Math & $\begin{array}{l}\text { Identify numbers, Identify, count and } \\
\text { locate objects; group objects by } \\
\text { characteristics }\end{array}$ \\
\hline \multirow[t]{2}{*}{ Behaviour Board } & Personal and social training & $\begin{array}{l}\text { Identity/self-esteem; } \\
\text { Democratic } \\
\text { coexistence/citizenship }\end{array}$ & $\begin{array}{l}\text { Awareness of belonging to a group } \\
\text { and respect for rules and others } \\
\text { members; ability to make choices and } \\
\text { assume responsibilities }\end{array}$ \\
\hline & $\begin{array}{l}\text { Expressions and } \\
\text { Communication }\end{array}$ & Visual Arts & $\begin{array}{l}\text { Ability to recognize elements of } \\
\text { visual communication }\end{array}$ \\
\hline \multirow{2}{*}{ Clothes of the World } & Knowledge of the world & $\begin{array}{l}\text { Science-physical/natural } \\
\text { world }\end{array}$ & $\begin{array}{l}\text { Identify physical, social and cultural } \\
\text { aspects of the community and } \\
\text { identify differences and similarities } \\
\text { with other communities; know and } \\
\text { respect cultural diversity }\end{array}$ \\
\hline & Personal and social training & $\begin{array}{l}\text { Identity/self-esteem; } \\
\text { Democratic } \\
\text { coexistence/citizenship }\end{array}$ & $\begin{array}{l}\text { Know and value manifestations of } \\
\text { cultural heritage; respect diversity; } \\
\text { accept their social and cultural } \\
\text { identity, in relation to others; } \\
\text { recognize and value social and } \\
\text { cultural ties }\end{array}$ \\
\hline \multirow[t]{2}{*}{$\begin{array}{l}\text { Preservation of } \\
\text { Heritage }\end{array}$} & Knowledge of the world & $\begin{array}{l}\text { Science-physical/natural } \\
\text { world; social world }\end{array}$ & $\begin{array}{l}\text { Recognize central elements of the } \\
\text { community, highlighting physical, } \\
\text { social and cultural aspects; identify } \\
\text { cultural practices; identify objects and } \\
\text { their properties }\end{array}$ \\
\hline & Personal and social training & $\begin{array}{l}\text { Independence/autonomy; } \\
\text { Democratic } \\
\text { coexistence/citizenship }\end{array}$ & $\begin{array}{l}\text { Know and value manifestations of } \\
\text { cultural heritage; recognize and value } \\
\text { social and cultural ties, recognizing } \\
\text { the need for preservation. }\end{array}$ \\
\hline
\end{tabular}

Busy Kids app exposes children to contents in the content area of knowledge of the world, suggested in the CGPE, such as knowing the community, life situations and cultural practices, but also, addresses the expression and communication area. Table 5 summarizes the learning that can be promoted by the Citizen Kids app, according to the CGPE. 


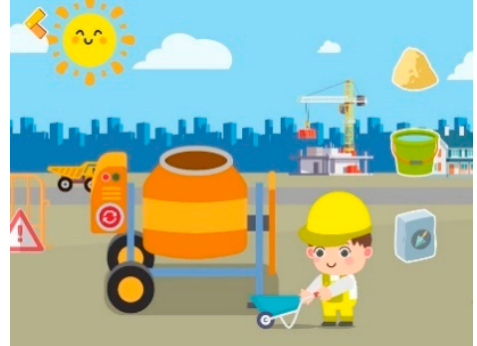

(a)

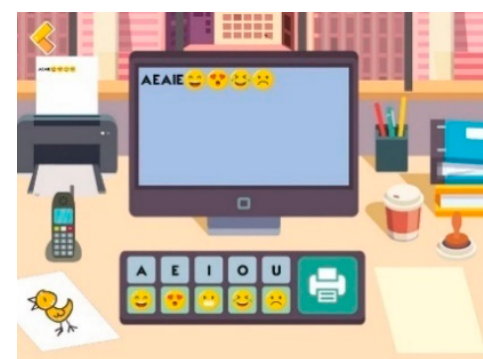

(b)

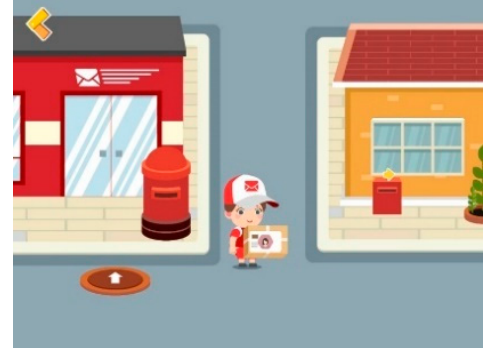

(c)

Figure 4. Print screens of games from the app Busy Kids: (a) Builder; (b) Office Worker; (c) Postman.

Table 5. Busy Kids games, content and learning.

\begin{tabular}{|c|c|c|c|}
\hline Game & Content Area & Knowledge Domain & $\begin{array}{l}\text { Learning, Attitudes, Know-How } \\
\text { That Can Be Explored }\end{array}$ \\
\hline \multirow[b]{2}{*}{ Postman } & Knowledge of the world & $\begin{array}{l}\text { Science-physical/natural/ social } \\
\text { world }\end{array}$ & $\begin{array}{l}\text { Knowing the community; life } \\
\text { situations and cultural practices; jobs } \\
\text { and routines. }\end{array}$ \\
\hline & $\begin{array}{l}\text { Expression and } \\
\text { communication }\end{array}$ & Math & $\begin{array}{l}\text { Group objects by characteristics; } \\
\text { locate objects, using orientation } \\
\text { concepts. Recognize locations and } \\
\text { maps. Follow an itinerary. }\end{array}$ \\
\hline \multirow{2}{*}{ Fashion Designer } & Knowledge of the world & Science-Social world & $\begin{array}{l}\text { Knowing the community; life } \\
\text { situations and cultural practices; jobs } \\
\text { and routines. Recognize properties of } \\
\text { different materials. }\end{array}$ \\
\hline & $\begin{array}{l}\text { Expression and } \\
\text { communication }\end{array}$ & Visual Arts; Math & $\begin{array}{l}\text { Recognize geometric figures; identify } \\
\text { patterns and symmetries. Develop } \\
\text { expressive/creative skills through } \\
\text { graphic compositions. }\end{array}$ \\
\hline \multirow[t]{2}{*}{ Builder } & Knowledge of the world & $\begin{array}{l}\text { Science-physical/natural/social } \\
\text { world }\end{array}$ & $\begin{array}{l}\text { Knowing the community; life } \\
\text { situations and cultural practices; jobs } \\
\text { and routines; Recognize properties of } \\
\text { different materials. }\end{array}$ \\
\hline & $\begin{array}{l}\text { Expressions and } \\
\text { Communication }\end{array}$ & Math & $\begin{array}{l}\text { Recognize geometric shapes and } \\
\text { figures; identify patterns and } \\
\text { symmetries. }\end{array}$ \\
\hline \multirow{2}{*}{ Office Worker } & Knowledge of the world & Science-Social world & $\begin{array}{l}\text { Knowing the community; life } \\
\text { situations and cultural practices; jobs } \\
\text { and routines. }\end{array}$ \\
\hline & $\begin{array}{l}\text { Expressions and } \\
\text { Communication }\end{array}$ & Math; Approach to writing; & $\begin{array}{l}\text { Recognize and write number, } \\
\text { Recognize and write letters; Be aware } \\
\text { of text directionality. }\end{array}$ \\
\hline \multirow[t]{2}{*}{ Mechanic } & Knowledge of the world & Science-Social world & $\begin{array}{l}\text { Knowing the community; life } \\
\text { situations and cultural practices; jobs } \\
\text { and routines. }\end{array}$ \\
\hline & $\begin{array}{l}\text { Expressions and } \\
\text { Communication }\end{array}$ & Visual Arts; & $\begin{array}{l}\text { Develop expressive and creative skills } \\
\text { through graphic compositions. }\end{array}$ \\
\hline
\end{tabular}

\subsubsection{Common Approach, Multidisciplinary Content and Integrating Website}

The apps are based on image (illustration, animation) and sound (music and sound effects), which are suitable ways to communicate with children, regardless of their native language and literacy level. Written text and audio narration were excluded. Scenarios are 
filled with interactive and animated elements, to incite children to freely explore different spots. Objects with small interactivity stimulate curiosity and discovery, as well as an understanding of the world around them (e.g., touching a perched bird, the bird flies; Touching a switch, the light turns on or off; Touch a tap, the water flows). These small interactions allow the child to appropriate concepts and make sense of the world. In certain games, there are concrete tasks. Other games have open rules, so children build freely and progress according to their will and speed.

In addition to the knowledge and skills immediately associated with each game, there are other learnings that are more subtly integrated to explore multidisciplinary, such as mathematics. In the Forest game, the child has to count and find the baby animals that parents had lost. In the Construction game, the player respects geometric shapes to create a wall. In the Postman game, children interpret maps to orient the character and move around. Other knowledge domains that are suggested in the CGPE can be explored with the Apps. One it the introduction to scientific methodology, which proposes to carry out activities that allow the child to question, hypothesize, predict responses, experiment, collect, organize and analyze information and draw conclusions. This type of activity can be promoted with the support of the educator, in the exploration of various games. Examples: which foods are healthy? What happens if the boy does not put on sunscreen? What do animals eat? How will the seed end up in fruit?

Additionally, the use of technologies is a learning area for CGPE-to recognize and use technological equipment, with care and safety. This is promoted by using tablets to play the apps, individually and autonomously, or in peer or group activities, with guidance from the educator.

These apps do not promote competition among children, but cooperation, since they all want to contribute to a better world, which is translated into a system of flowers in a virtual world. When children play a game, a flower appears in a virtual world inside the app, symbolizing their individual participation. But they can also send their contribution to the project's website, where all the flowers of all the children are represented. It symbolizes their total participation in the global world (Figure 5).

This aggregator site gathers data on the use of apps and shows the contribution of all users to a better world. Children can see the graphic representation of a world in which they participate. Thus, children begin to learn that their actions have a personal impact and a global impact, and they feel that they have contributed to a better future, which is extremely important in environmental, citizenship, public health, economy and employment issues, the main themes of the apps. On this website, parents and educators find educational guides for each app, with the objectives of the games, how to play, conversation topics before, during and after playing the games, and suggestions for educational activities to do with the children.

\subsection{Results of the Evaluation Phase}

The results of the observation (children using the apps) and the interview (educator's perception) served to implement corrections and improvements in the final versions of the apps, in order to make the products more efficient for educational activities in kindergarten and to achieve a greater interest and involvement of the children. A pilot study report details all the improvements made in each game, in the four apps [51]. For this article, the results of each observation session are summarized, stating the main improvements made in the final versions of the apps. 


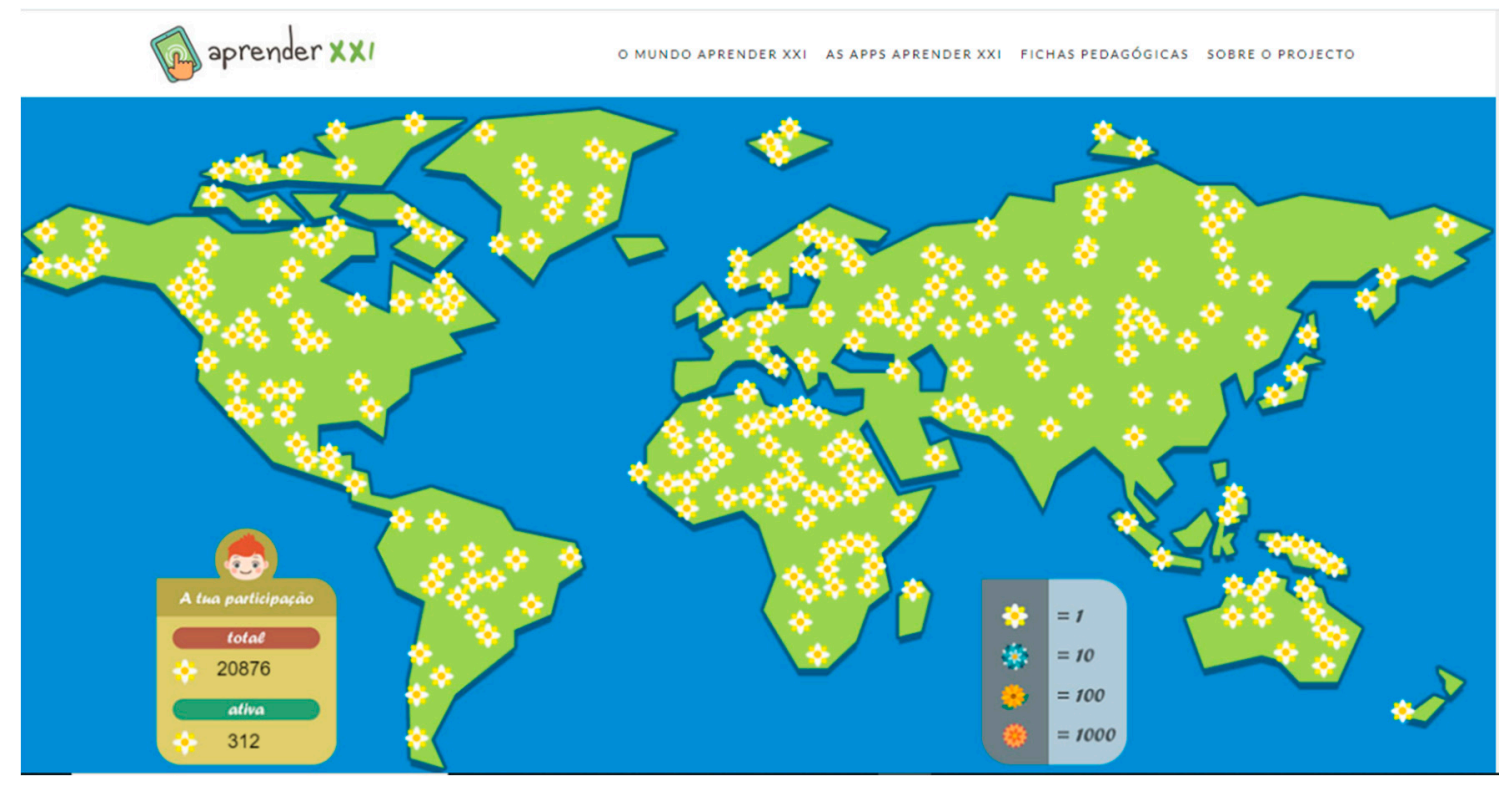

Figure 5. Children's participation in the Aprender XXI World.

\subsubsection{Observation Session of the Nature Kids App}

In the Forest game (delivering baby animals to their parents), some children ( $\mathrm{C} 2, \mathrm{C} 7$, $\mathrm{C} 11, \mathrm{C} 18$ ) found it difficult to catch the baby animals, as they were very small (squirrel and rabbit). The animals were enlarged in the final version. C13 found two baby animals and tried to pick them at the same time, which was not possible. It was also fixed. The game always started with the same animals and the children wanted to see them in another order. It was necessary to make it random. In the Meteorology game (Figure 6) (dressing characters according to the weather) the gameplay had to be explained to the first children who played (C4, C6, C8). They did not understand how to change the climate and how to see different clothes. This confirmed the need to implement graphic instructions and feedback to guide the action, for autonomous use by children. C20 found an error, which has been fixed. A character dressed according to the weather did not look happy. The game Feeding the Farm Animals was not well understood. Children did not understand that the animals were making specific requests, using speech bubble (meat, fish, water...) and that they had to satisfy the needs requested at that time. They played the game without obeying the rules, feeding the animals as they wanted. C11 gave the dog meat, then she gave him water because he could be thirsty. The dog had made no request at all. After the researcher explained the gameplay, children found it difficult to satisfy the requests at the right time. It was decided to remove this rule from the game. The objective changed to feed the animals, without having to obey time or specific requests, but according to the animal's diet (carnivore, herbivore, granivore). Graphic feedback was implemented, showing whether the animal liked it or not. The educator suggested that the animals could respond positively with a heart. The Plantations game also had to be changed. The game had several actions-sowing/planting, watering, fertilizing, harvesting. Since the children planted, the plantations started to grow and were ready to be harvested, regardless of whether the children carried out the actions. Children took some time to do these actions. $\mathrm{C} 2$ planted strawberries and harvested, without taking any intermediate action. The game has been corrected to make some steps mandatory for plants to grow. The Recycling game generated collaboration and communication. C5 and C6 played together, passing the tablet to each other. Several children pointed out the right container and commented where each type of garbage should be placed. 


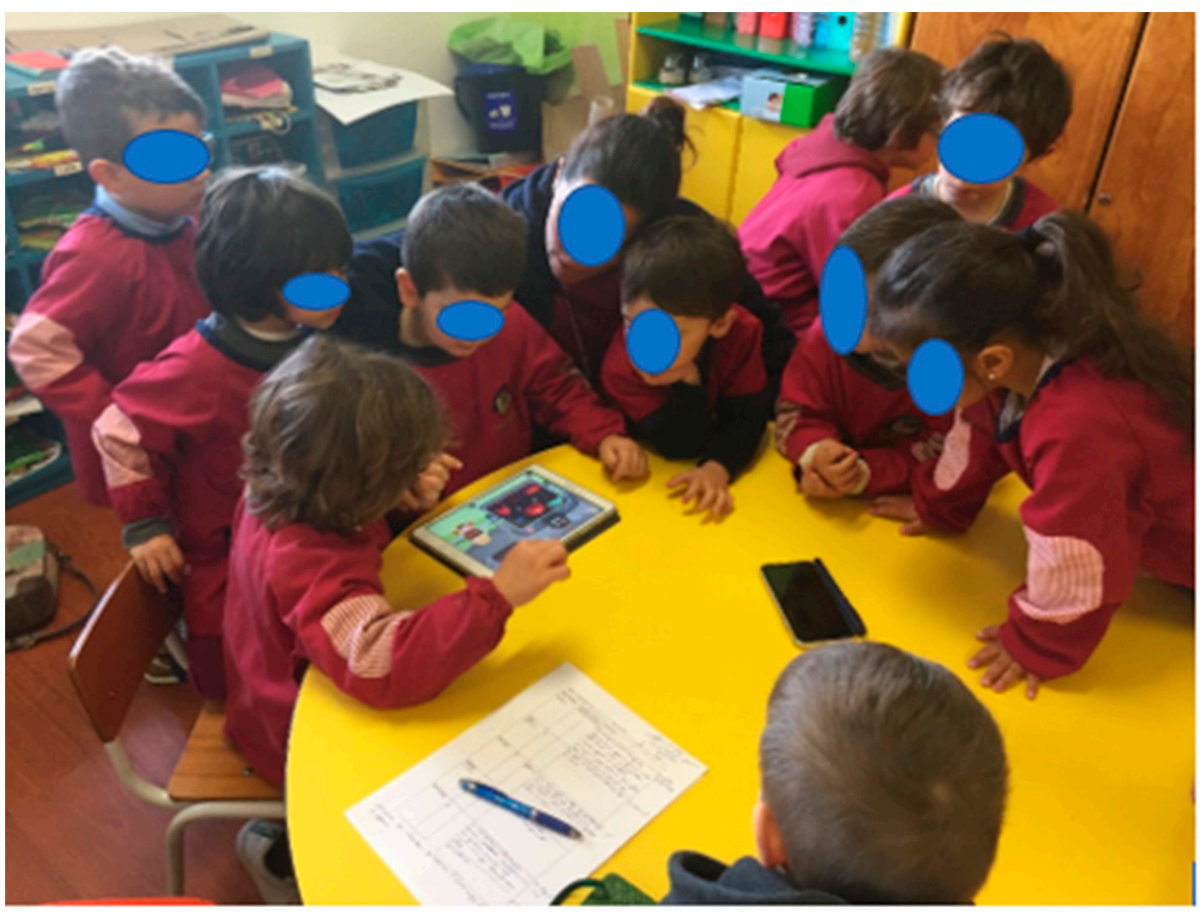

Figure 6. Child playing the Meteorology game, educator guiding, several classmates watching.

\subsubsection{Observation Session of the Healthy Kids App}

In the Supermarket game, C22 was the first to play and immediately understood the game. He chose assorted food on the shelves and went to the cashier to pay. The cash register screen showed a sad face when the chosen foods were not healthy. C22 repeated the game, buying only healthy foods. The rest of the children commented, to help him choose the right food. $\mathrm{C} 1$ found a bug, which was fixed in the final version. He put the character of the game walking in the opposite direction. The character left the screen and did not appear again. In the Dentist game, C10 was the first to play. He did not realize that he had to clean all teeth in the exposed mouth. He received an explanation from the researcher and followed the rest of the steps to the end, without any doubt. The educator felt that there was little distinction between step 2 (removing the caries and opening a cavity in the tooth) to step 3 (putting mass on the tooth). The cavity and the mass looked similar. In the final version, changes in shape and color were made in both steps. The instruments were difficult to use on the lower teeth, even for five-year-old children. It has been corrected by increasing the touch area on the screen. In Creating Healthy Snacks game, C12 found it very fun to create a giant sandwich and a drink with all the elements available. Then, the educator told her to create a healthy sandwich. Other children gave suggestions and commented. The game was well accepted, with no doubts or need for changes. The Beach game was well understood. C8 found an error. He was unable to give the character water to drink. He dragged the bottle to his mouth, but nothing happened, and the character continued to show thirst (Figure 7). It was necessary to increase the touch area of the mouth. The Physical Activity game did not attract so much interest or any interaction with each other. Children entered the garage, chose a prop (skateboard, bicycle, rollerblades) for the character, used it outdoors, in the garden, and left the game. 


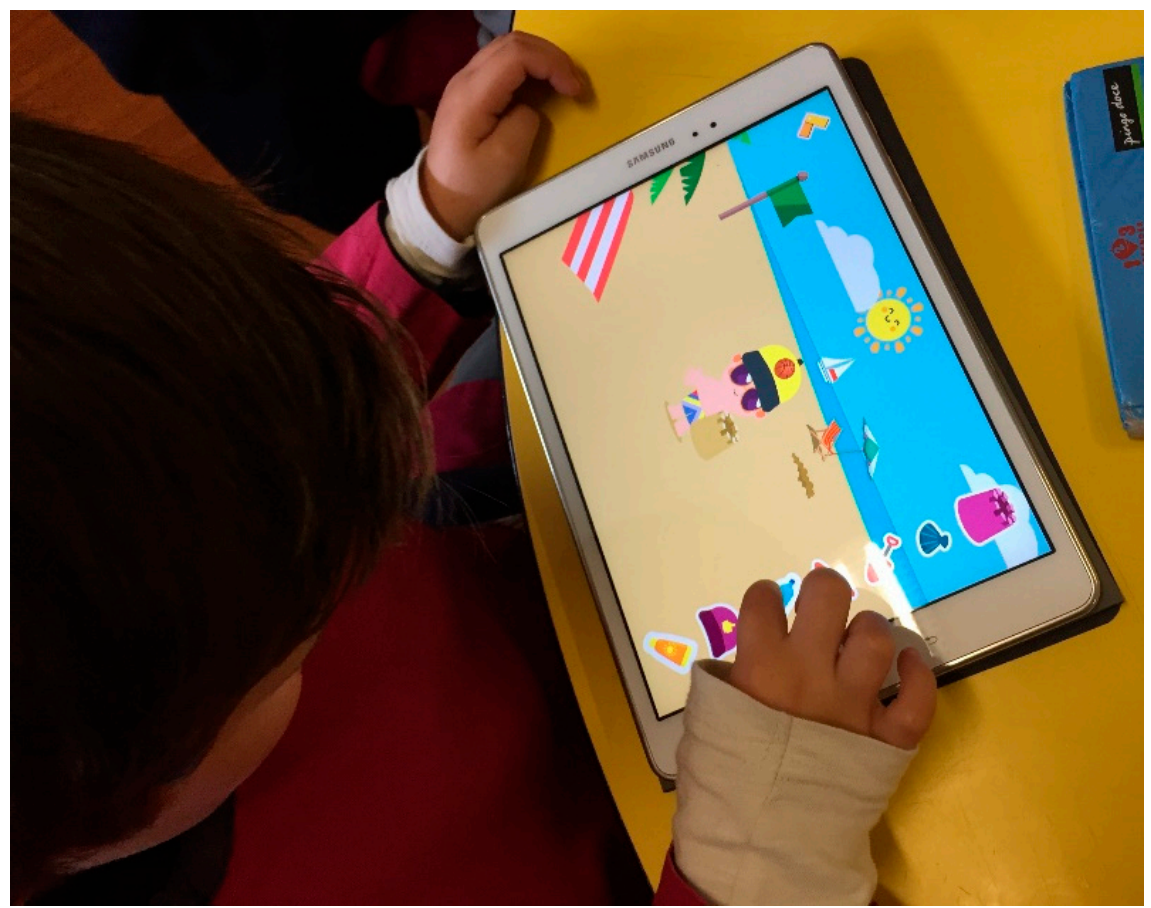

Figure 7. Detail of child playing the Beach game, trying to give water to the character.

\subsubsection{Observation Session of the Citizen Kids App}

The games Play Areas and Playground (Figure 8) were highly requested, being played by eight and nine children, respectively. In both games, children wanted to move the characters to different areas and see if they were happy. The other children watched and made comments that indicated they understood the games. Some comments: C3 (while watching) - "you are always moving them around!"; C4 (while playing) - "because they want to"; C12 (while watching) - “Otherwise, they will be sad!"; C3-“But they have to wait". In certain interactions, children dragged a character to an area, but it did not stay there. This was fixed in the final version, in both games. The game Board of Behaviors was not well understood, even by the five-year-old children. It was necessary to explain everything, step by step. They did not realize that the board had one area for the right behaviors and another for the wrong behaviors. In the final version, it was necessary to change the graphics to better delineate the different areas. C8 played the game under the guidance of the researcher and did not like it. C14 also needed guidance, but he filled the board to the end. It was necessary to improve the game, for autonomous use, inserting graphical explanations and feedbacks. The game Preservation of heritage was understood and played six times by children aged three, four and five. The game has a path with tasks, which were carried out by children without the need for explanation. After finishing the game, C19 made the course again without stopping, trying to be the fastest. The others commented, interested. It was possible to notice that they already knew the tasks (e.g., C12- "Next, you have to clean the posters on the wall"). In the game Clothes of the World, $\mathrm{C} 13$ and $\mathrm{C} 15$ had difficulty dragging shoes and glasses. The need to increase the size of these elements was noted and corrected in the final version. They also did not realize that they could choose another country by touching the map, nor change the clothes inside the closet, by closing and opening its doors. It was necessary to add visual clues. 


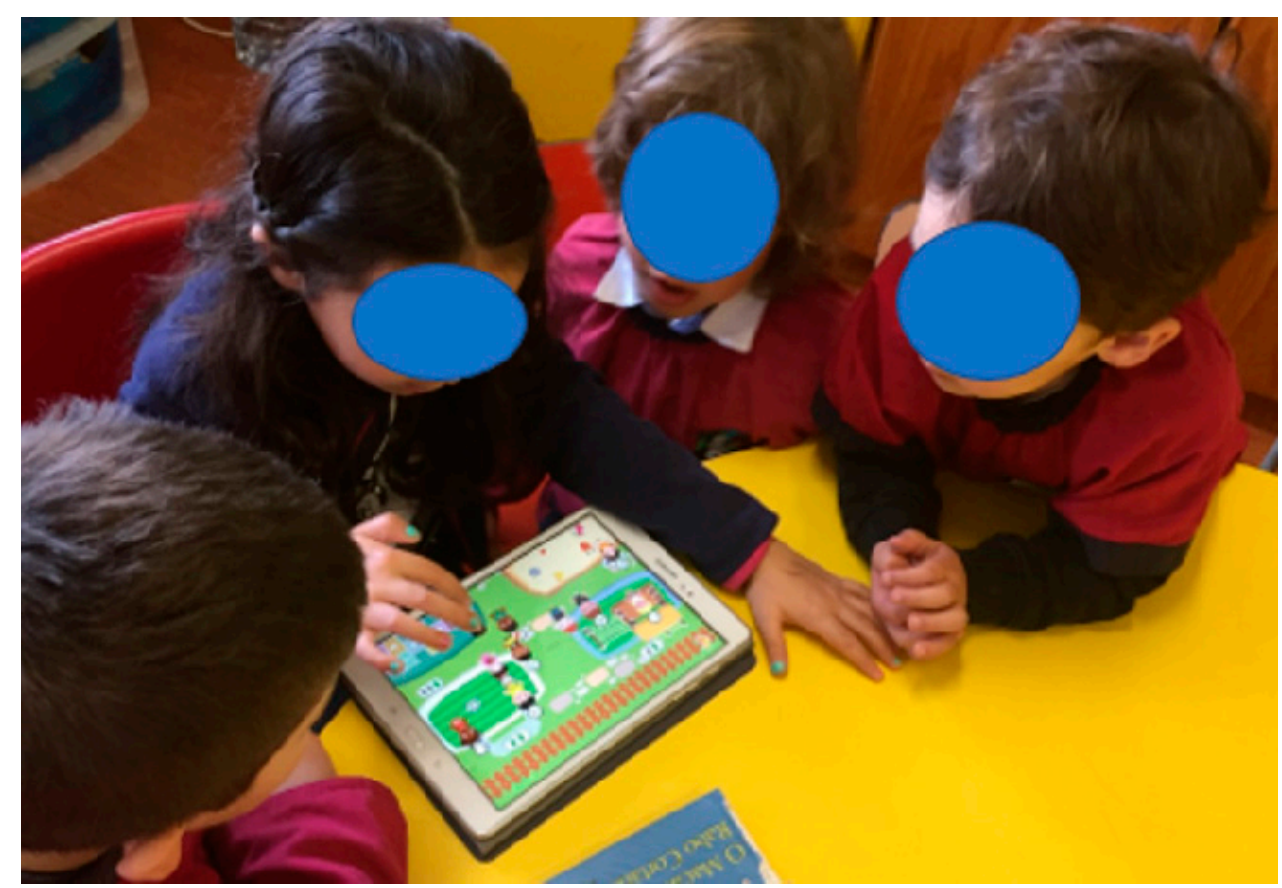

Figure 8. Child playing autonomously the game Playground. Friends watching and commenting.

\subsubsection{Observation Session of the Busy Kids App}

The most chosen game of all apps was the Builder game, played by 15 children (Figure 9). Some played together, in collaboration. Three-year-old C2 was the first to play. As he had doubts, the researcher explained the game and all the children listened. However, some difficulties have arisen. The interaction for making cement consisted of touching the materials and touching the machine's switch to turn it on. Seven children tried to drag the materials into the machine and nothing happened. In the final version, the interaction was changed, from touching to dragging, to be more intuitive. They also did not realize that they had to press the switch to start the cement machine. The size of the switch and the luminous graphic feedback were increased. In the second part of the game, they had to build a wall, but five children did not take the trowel to put the cement. It has been corrected by highlighting the trowel in the instrument menu. After placing the cement and brick, four children took the hammer and broke the brick, not understanding the function of the hammer. It was necessary to separate the construction instruments from the destruction instruments in the menu. As the walls could have different shapes, the educator considered that this was a good game to learn mathematics. The game Fashion Designer was not spontaneously chosen by any child. C18 volunteered at the end, to experiment. The researcher explained the first step-choosing a fabric. From there, he played alone, without difficulty, understanding all the possibilities. In the Office Worker game, C15 was the first to play. She thought the goal was to write on the computer that appeared in the game. It was explained to her that she could explore other office supplies (phone, pad, pens, among others). The game's keyboard was simplified, it only contained vowels, space key and emojis. The educator suggested placing a virtual keyboard with all the letters, so that the children could practice writing. She also considered that the phone was useful for children to train their parents' contact numbers. The change to the keyboard was not implemented, due to lack of space on the game screen. The Postman game also had to be explained. The first part, separating the types of letters and packages, was apprehended immediately. The second part, delivery mail following a map and arrows, was more difficult to understand and play. However, the gameplay remained, because it trains important skills, such as orientation, interpretation of maps and the sense of laterality. The Mechanic game was easily understood, although there were doubts about the tools for fixing dents, filling tires 
and painting. It was necessary to change the illustrations of these items. Three-year-old C16 spent four minutes decorating the car, worried about the aesthetic.

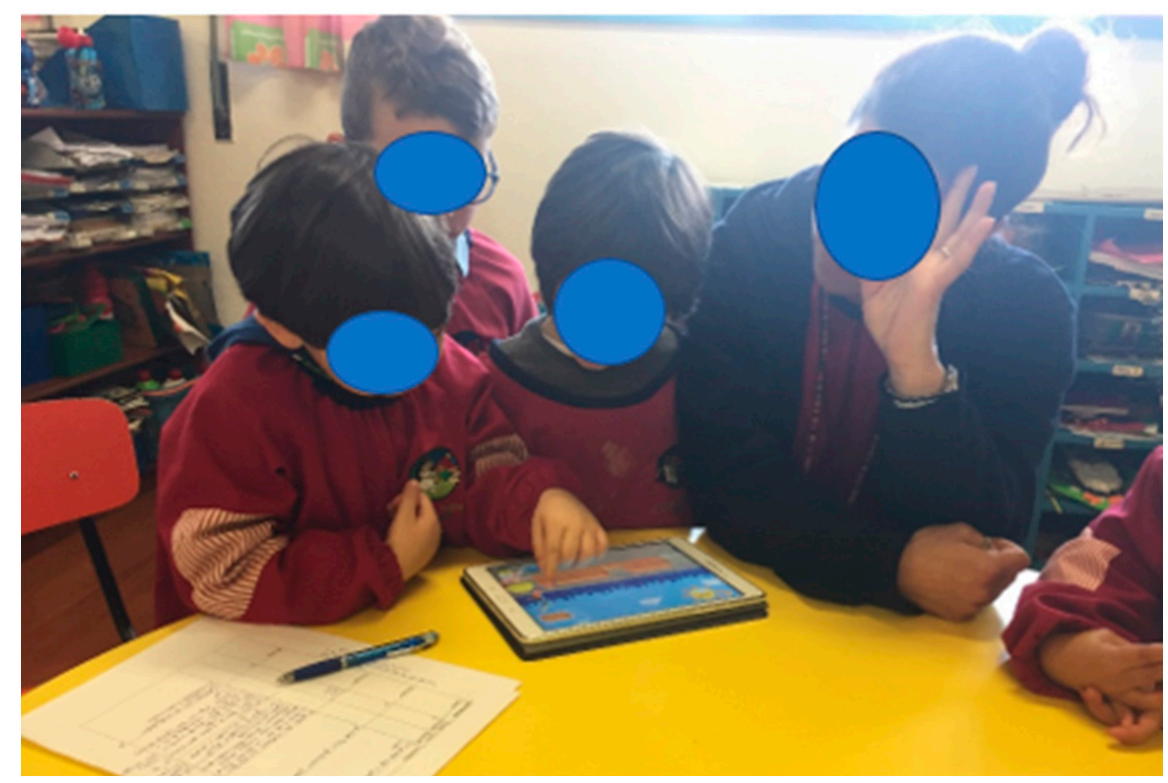

Figure 9. Children collaborating, playing together the Builder game, educator helping.

\subsubsection{Interview with the Kindergarten Educator}

The interview with the educator aimed to obtain information to characterize the context where the tests took place and to evaluate the apps, as to relevance (content validity), consistency (construct validity) and expected practicality, that is, to understand if the educator would use the product and identify obstacles to its use [35].

Regarding the context, the educator already carried out technological activities with the children, such as watching videos on YouTube ${ }^{\circledR}$, searching on Google ${ }^{\circledR}$, printing images. In the kindergarten classroom, they had a computer, where children could write letters or draw pictures. The educator also promoted digital communication. Children used Messenger ${ }^{\circledR}$ in kindergarten to send emojis to their parents. The educator used Skype ${ }^{\circledR}$ to make video calls with the children, when they were sick at home. They did not have a tablet in the kindergarten room, but the educator recognized that it was the most appropriate and preferred device. Regarding the expectation of use, the educator did not know many learning apps and thought that the Aprender XXI apps were in accordance with the interests of the children and the thematic areas they usually work on. The educator liked all the apps and gave concrete suggestions in some games. One suggestion was for games where the buttons are integrated into the scenario. A greater distinction should be made between buttons that have interaction and scenery props that are only illustrative. It can be a visual cue on the buttons (brightness, animation) or, after some time without action, a help could appear, such as an arrow indicating a path. The educator also had suggestions about the structure and content of the educational guides for parents and educators. It could be a guide per game. Each guide should have an introduction about the game, goals and gameplay, so that the educator understands it first and then can explain the game to the children, guide the use and plan activities. Regarding the advantages, the educator said that this type of activity is very stimulating for children, pleases them and transmits knowledge in the way they like. It also promotes communication and collaboration in a joint activity. As for the constraints, she indicated lack of time, the size of the group and the lack of equipment. This is a very large group ( 22 children) to give personalized attention in this type of activity, which is something that all the children want to do at the same time. Referring to the devices, she said that due to the results of this activity, 
she would ask the institution or even the parents, to purchase tablets for the classroom's educational activities.

After the evaluation with users, changes were made to the games and the final versions of the apps were completed. The project ended with the release of the four apps on the App Store ${ }^{\circledR}$ (iOS 8.0) and Google Play ${ }^{\circledR}$ (Android 4.0.3), the online publication of the website with the virtual world that flourishes with the participation of children in apps, and educational guides for parents and educators.

\section{Discussion}

Following the DBR methodology, the project Aprender XXI was divided into three phases: preliminary study, development and evaluation. The preliminary study served as a theoretical framework for contextualizing and supporting the project, and to identify the existing needs that helped define the objectives and content of the apps. The search for educational apps suitable for these ages allowed to know the "state of the art" and understand the existing offer in the market that can be used in an educational context, as well as to identify limitations and opportunities for development. To end this phase, Portuguese curriculum guidelines for pre-school education were studied, along with guidelines from other countries. The analysis of data collected in the preliminary study was essential in the development phase-definition of specifications, selection of contents, scriptwriting, design and programing of the games. The theoretical knowledge was integrated in a practical way in the apps, such as opting for open games (e.g., Office Worker) or games that allowed to manipulate several variables (e.g., Meteorology, Mechanic), because they have a greater cognitive and creative contribution, and promote group interaction and communication $[23,25]$. Games were planned to allow children to experiment different scenarios, to solve challenges (e.g., Builder, Healthy Snacks), to respect rules (e.g., Behavior Board, Playground, Play Areas), providing variety and flexibility of learning [28]. Design decisions considered the literature: use of illustrations and animations that provide context; have a simple interface and interactivity that is easy to learn and use; image-based feedback related to actions [24]. The search for apps in the market showed a lack of apps suitable for educational activities in kindergarten, according to CGPE and in Portuguese language. The content chosen was based on the areas suggested in pre-school education guidelines [29], adapted to games that could be used by educators in a multidisciplinary way, combining, for example, mathematics, geography, citizenship and environment [21].

The kindergarten sessions were important to test the products with the public (children and educator), to verify the need to change the course of development or to continue the implementation according to the plan. The results of the evaluation showed that the apps met the interests of the children, were pedagogically useful and provided a new educational tool for the educator. In this way, the evaluation validated the options that had been taken in the development phase. There were also evaluation results that added knowledge and led to improvements in the games. It became clear the importance of making interactive elements more visible, so lighting effects or animation were added to the buttons feedback, and some objects or outlines were increased. Visual instructions were introduced in all games to guide children in their autonomous use. Some games had specific corrections, as a result of observing their use by the children. Minor bugs were also detected and fixed. These corrections were made, before the release of the final versions of the apps in the Stores, that were linked to the website, with the flower system to visualize the cooperation and participation of children.

\section{Conclusions}

This project aimed to develop game-based learning apps for preschoolers, using the DBR methodology to support technological development with scientific research in the area of technologies in education. The information collected in the three phases (preliminary study, development and evaluation), the involvement of the target audience (educator and children) and the triangulation with theoretical studies and existing apps guided the 
technological development, resulting in robust products and contributions to the theory. Summarizing some principles of this study:

- CGPE is a guiding document that presents areas of content and learning for children in kindergarten, reiterating the importance of playing as a primary form of learning.

- The areas of expression and communication, knowledge of the world and personal and social training are divided into domains of knowledge, with learning potential. These content areas were included in the apps, to meet the needs of pedagogical activities in the kindergarten, respecting the CGPE.

- Extensive literature documents the benefits of using technology in children's learning, in different content areas and knowledge domains. In Portugal, there are limitations in the apps available on the market, regarding the learning promoted for these ages.

- In the literature, there are recommendations for the creation of multimedia resources for children, such as the use of graphics and actions that provide context; simple instructions based on images; intuitive interface and interactivity; challenging approach with multiple opportunities for success; clear and understandable feedback. Digital games are a very appealing type of multimedia content for children.

- These recommendations were followed in the development of apps and their relevance was confirmed in tests with users in kindergarten. The tests also made it possible to find and correct bugs, identify improvements to be developed in the final versions of the apps and validate their educational value with the educator.

Some limitations to the study are related to characteristics of the DBR methodology and to the development context, a micro company where the researcher is also a project manager. It was necessary to involve and combine several people with different profiles and rhythms-researchers, technological team and target audience [52]. Scientific research requires time to collect and analyze data at each stage. The involvement of the educator and children is conditioned by timetables, school calendars and pedagogical plans, so it was necessary to adjust the research to these restrictions to achieve their participation. The company's team had reduced availability, because it had several projects with tasks and deadlines running at the same time. This resulted in a limitation of the project, which was the impossibility of involving the target audience in all phases, particularly in the preliminary study, to survey the needs. It would be interesting in a later version, to include questionnaires or focus groups involving the target audience from the beginning. Another limitation is the difficulty in generalizing the results, since, in DBR, the sample of participants is not representative of reality, but rather small and intentional [32]. Thus, the products are tested with small groups of users and released on the market. Subsequently, with continued use and new data, they evolve to improved versions. Thus, the design principles presented in this article follow the recommendations of several authors [32,33,53], to be contextualized, so that they can be interpreted, adapted and contribute to knowledge. It would be interesting to repeat the evaluation in other kindergarten classrooms to increase the degree of generalization.

In terms of impact for end users, the results of the evaluation indicate that the products have the potential to promote the learning of pre-school children, since the games have contents covered in kindergarten, the children showed interest in playing the games and the educator identified possible educational activities to do with apps. A more in-depth case study on the use of apps in kindergarten would be interesting to measure learning outcomes and suggest an implementation plan in the classroom, with a certain number of sessions, duration and learning objectives.

As a final note, the researcher considers that the project Aprender XXI is an example of good practice, for a research project developed in a business context in the area of education technologies. The project represented a business effort to reinforce internal R\&D skills to create knowledge and greater competitiveness. It stimulated technological experimentation and scientific dissemination led by an SME. The results (four apps in two stores) were able to generate value for the company and integrate an initial internationalization strategy. 
Funding: This research was funded by the European Union through the European Regional Development Fund, the 2020 Center Program, under the project “Aprender XXI: Game-based m-learning for children in kindergarten", grant number CENTRO-01-0247-FEDER-009828).

Institutional Review Board Statement: Ethical approval was not sought for the present study because no more than minimal risk was identified. This study meets the necessary ethical requirements and does not include activities or results that pose safety problems for the participants. Data were properly anonymized and informed consent was obtained at the time of original data collection. Data storage meets current Data Protection regulations.

Informed Consent Statement: Informed consent was obtained from all subjects involved in the study, with the assent of children and permission of their parents.

Data Availability Statement: Data are contained in supplementary material, available in open access on Zenodo [43,51]. The following supplementary materials are available online: website (http:/ / aprenderxxi.criamagin.com) (accessed on 5 April 2021); App Nature Kids (https://itunes. apple.com/us/app/nature-kids/id1459394172 (accessed on 5 April 2021) e https://play.google. com/store/apps/details?id=com.criamagin.naturakids (accessed on 5 April 2021)); App Healthy Kids (https:/ /itunes.apple.com/us/app/healthy-kids/id1459395328 (accessed on 5 April 2021) e https:/ / play.google.com/store/apps/details?id=com.criamagin.healthykids (accessed on 5 April 2021)), App Citizen Kids (https:/ /itunes.apple.com/us/app/citizen-kids/id1459383445 (accessed on 5 April 2021) e https:/ / play.google.com/store/apps/details?id=com.criamagin.citizenkids (accessed on 5 April 2021)); App Busy Kids (https:/ /itunes.apple.com/us/app/busy-kids/id1459400995 (accessed on 5 April 2021) e https:/ / play.google.com/store/apps/details?id=com.criamagin.busykids (accessed on 5 April 2021)).

Acknowledgments: The author thank the reviewers for their insightful comments.

Conflicts of Interest: The author declares no conflict of interest. The funders had no role in the design of the study; in the collection, analyses, or interpretation of data; in the writing of the manuscript, or in the decision to publish the results.

\section{References}

1. Prensky, M. Digital Natives, Digital Immigrants Part 1. Horizon 2001, 9, 1-6. [CrossRef]

2. Thomas, M. Deconstructing Digital Natives: Young People, Technology, and the New Literacies; Routledge: New York, NY, USA, 2011.

3. Hattie, J.; Yates, G. Your Students Are Digital Natives. Or Are They? In Visible Learning and the Science of How We Learn; Routledge: New York, NY, USA, 2013.

4. Chaudron, S. Young Children (0-8) and Digital Technology: A Qualitative Exploratory Study across Seven Countries; EUR 27052 EN; ISPRA, Joint Research Centre: Ispra, Italy, 2015.

5. Marsh, J.; Kontovourki, S.; Tafa, E.; Salomaa, S. Developing Digital Literacy in Early Years Settings: Professional Development Needs for Practitioners. White Paper Cost Action IS1410. 2017. Available online: http://digilitey.eu/wp-content/uploads/2017 /01/WG2-LR-jan-2017-1.pdf (accessed on 10 April 2021).

6. Cordes, C.; Miller, E. Fool's Gold: A Critical Look at Computers at Childhood; ED 445 803; Alliance for Childhood: College Park, MD, USA, 2000.

7. Cuban, L. Cyberteaching in Preschools and Kidergartens. In Oversold and Underused Computer in the Classroom; Harvard University Press: Cambridge, MA, USA, 2001.

8. Mayer, R. Learning with Technology. In The Nature of Learning Using Research to Inspire Practice; Dumont, H., Instance, D., Benavides, F., Eds.; OECD Centre for Educational Research and Innovation: Paris, France, 2010; pp. $179-196$.

9. NAEYC. Fred Rogers Center for Early Learning and Children's Media. Technology and Interactive Media as Tools in Early Childhood Programs Serving Children from Birth through Age 8. In Joint Position Statement; NAEYC: Washington, DC, USA, 2012.

10. Chassiakos, Y.; Radesky, J.; Christakis, D.; Moreno, M.; Cross, C.; Council on Communications and Media. Children and Adolescents and Digital Media. Pediatrics 2016, 138, e20162593.

11. Burnett, C. Technology and Literacy in Early Childhood Educational Settings: A Review of Research. J. Early Child. Lit. 2010, 10, 247-270. [CrossRef]

12. Hsin, C.; Li, M.; Tsai, C. The Influence of Young Children's Use of Technology on Their Learning: A Review. Educ. Technol. Soc. 2014, 17, 85-99.

13. Lieberman, D.; Bates, C.; So, J. Young Children's Learning with Digital Media. Comput. Sch. 2009, 26, 271-283. [CrossRef]

14. Amante, L. As TIC Na Escola e No Jardim de Infância: Motivos e Factores Para a Sua Integração. Sísifo Rev. Ciênc. Educ. 2007, 3, 51-64. 
15. Amante, L.; Faria, Á. Sentido(s) Emergente(s) Das Tecnologias Digitais No Jardim de Infância. In Ensinar e Aprender Online Com Tecnologias Digitais: Abordagens Teóricas e Metodológicas; Moreira, J.A., Monteiro, A., Eds.; Porto Editora: Porto, Portugal, 2012; pp. $45-64$.

16. Ramos, A. Crianças, Tecnologias e Aprendizagem: Contributo Para Uma Teoria Substantiva. Ph.D. Thesis, Universidade do Minho, Braga, Portugal, 2005.

17. Clements, D. Young Children and Technology; ERIC: Washington, DC, USA, 1998.

18. Ramos, A. Crianças, Tecnologias e Aprendizagem: Contributos Para Uma Teoria Substantiva. A Minha Tese de Doutoramento ... Mais de Dez Anos Depois. In Pesquisar; Chiado Editora: Lisboa, Portugal, 2018; pp. 23-52.

19. Common Sense Media. The Common-Sense Census: Media Use by Kids Age Zero to Eight; Common Sense Media: San Francisco, CA, USA, 2017.

20. Ponte, C.; Simões, J.; Batista, S.; Jorge, A.; Castro, T. Crescendo Entre Ecrãs: Usos de Meios Eletrónicos Por Crianças (3-8 Anos); ERC—Entidade Reguladora da Comunicação Social: Lisboa, Portugal, 2017.

21. Gardner, H.; Davis, K. The App. Generation: How Today's Youth Navigate Identity, Intimacy, and Imagination in a Digital World; Yale University Press: New HAvem, CT, USA, 2013.

22. Clarke, B.; Svanaes, S. An Updated Literature Review on the Use of Tablets in Education; Tablets for Schools; Family Kids \& Youth: London, UK, 2014.

23. Goodwin, K.; Highfield, K. ITouch and ILearn: An Examination of "Educational" Apps. In Proceedings of the Early Education and Technology for Children Conference, Salt Lake City, UT, USA, 14-16 March 2012; pp. 14-16.

24. Clements, D.; Sarama, J. Teaching with Computers in Early Childhood Education: Strategies and Professional Development. J. Early Child. Teach. Educ. 2002, 23, 215-226. [CrossRef]

25. Hillman, M.; Marshall, J. Evaluation of Digital Media for Emergent Literacy. Comput. Sch. 2009, 26, 256-270. [CrossRef]

26. Papert, S. The Connected Family: Bridging the Digital Generation Gap; Longstreet Press: Atlanta, GA, USA, 1996.

27. Prensky, M. Digital Game-Based Learning. Comput. Entertain. 2003, 1, 21-25. [CrossRef]

28. Gros, B. Digital Games in Education: The Design of Games-Based Learning Environments. J. Res. Technol. Educ. 2007, 40, 23-38. [CrossRef]

29. Silva, I.; Marques, L.; Mata, L.; Rosa, M. Orientações Curriculares Para a Educação Pré-Escolar; Ministério da Educação: Lisboa, Portugal, 2016.

30. van den Akker, J.; Gravemeijer, K.; Mckenney, S.; Nieveen, N. Introducing Educational Design Research. In Educational Design Research; Routledge: New York, NY, USA, 2006; pp. 3-7.

31. Brown, A. Design Experiments: Theoretical and Methodological Challenges in Creating Complex Interventions in Classroom Settings. J. Learn. Sci. 1992, 2, 141-178. [CrossRef]

32. van den Akker, J. Principles and Methods of Development Research. In Design Approaches and Tools in Education and Training; van den Akker, J., Branch, R., Gustafson, K., Nieveen, N., Plomp, T., Eds.; Springer Science \& Business Media: Berlin/Heidelberg, Germany, 1999; pp. 1-22.

33. Plomp, T. Educational Design Research: An Introduction. In Educational Design Research; Plomp, T., Nieveen, N., Eds.; Institute for Curriculum Development: Enschede, The Netherlands, 2013; pp. 10-51.

34. The Design-Based Research Collective. Design-Based Research: An Emerging Paradigm for Educational Inquiry. Educ. Res. 2003, 32, 5-8. [CrossRef]

35. Nieveen, N.; Folmer, E. Formative Evaluation in Educational Design Research. Des. Res. 2013, 153, $152-169$.

36. Reeves, T. Enhancing the Worth of Instructional Technology Research through "design Experiments" and Other Development Research Strategies. In International Perspectives on Instructional Technology Research for the 21st Century; Annual Meeting of the American Educational Research Association: New Orleans, LA, USA, 2000.

37. Garrett, J. The Elements of User Experience: User-Centered Design for the Web and Beyond, 2nd ed.; Pearson Education: London, $\mathrm{UK}, 2003$.

38. Sova, D.; Nielsen, J. 234 Tips and Tricks for Recruiting Users as Participants in Usability Studies; Nielsen Norman Group: Fremont, CA, USA, 2003; p. 190.

39. Creswell, J. Collecting Qualitative Data. In Educational Research: Planning, Conducting and Evaluating Quantitative and Qualitative Research; Pearson Education: London, UK, 2012.

40. Cohen, L.; Manion, L.; Morrison, K. Research Methods in Education; Routledge: London, UK, 2007.

41. Fraenkel, J.; Wallen, N. Observation and Interviewing. In Design and Evaluate Research in Education; McGraw-Hill Higher Education: New York, NY, USA, 2009; pp. 439-470.

42. Bogdan, R.; Biklen, S. Trabalho de Campo: O Contínuo Participante/Observador. In Investigação Qualitativa em Educação: Uma Introdução à Teoria e aos Métodos; Porto Editora: Porto, Portugal, 1994; pp. 125-133.

43. Laranjeiro, D.; Laranjeiro, J.; Mouta, L.; Zagalo, N. Relatório de Estudos Preliminares do Projeto Aprender XXI; Criamagin: Aveiro, Portugal, 2017. [CrossRef]

44. Couse, L.; Chen, D. A Tablet Computer for Young Children? Exploring Its Viability for Early Childhood Education. J. Res. Technol. Educ. 2010, 43, 75-96. [CrossRef]

45. Sandvik, M.; SmØrdal, O.; Østerud, S. Exploring IPads in Practitioners' Repertoires for Language Learning and Literacy Practices in Kindergarten. Nord. J. Digit. Lit. 2012, 7, 204-221. [CrossRef] 
46. Zaranis, N.; Kalogiannakis, M.; Kontovourki, S. Using Mobile Devices for Teaching Realistic Mathematics in Kindergarten Education. Creat. Educ. 2013, 4, 1-10. [CrossRef]

47. Dominguez, A. IPads Na \#sala5; Universidade de Lisboa, Instituto de Educação: Lisboa, Portugal, 2013.

48. Pereira, A.; Moraes, A. Possibilidades De Uso Do Tablet Na Educação Infantil. Rev. Semin. Midias E Educ. 2015, 1, $423-426$.

49. Zagalo, N.; Laranjeiro, D. Brinquedos e Jogos Digitais Para o Jardim de Infância. In Atas do 4.o Encontro sobre Jogos e Mobile Learning; Centro de Estudos Interdisciplinares do Século XX: Coimbra, Portugal, 2018; pp. 479-489.

50. European Commission/EACEA/Eurydice/Eurostat. Key Data on Early Childhood Education and Care in Europe; Eurydice and Eurostat Report 2014 Edition; Publications Office of the European Union: Luxembourg, 2014.

51. Laranjeiro, D. Relatório Do Estudo Piloto-Projeto Aprender XXI; Criamagin: Aveiro, Portugal, 2019. [CrossRef]

52. Kelly, A.; Baek, J.; Lesh, R.; Bannan-Ritland, B. Enabling Innovations in Education and Systematizing Their Impact. In Handbook of Design Research Methods in Education-Innovations in Science, Technology, Engineering and Mathematics Learning and Teaching; Kelly, A., Baek, J., Eds.; Routledge: New York, NY, USA, 2008; pp. 3-19.

53. Bannan-Ritland, B. The Role of Design in Research: The Integrative Learning Design Framework. Educ. Res. 2003, 32, 21-24. [CrossRef] 